\title{
Treatment of Zygomatic-Orbital Complex Fracture Through Transconjunctival Approach
}

\author{
Tratamiento de la Fractura del Complejo Cigomático-Orbital \\ Mediante el Acceso Transconjuntival
}

Guilherme dos Santos Trento*; Bruno Tochetto Primo*; Paola Fernanda Cotait de Lucas Corso*; Nelson Luis Barbosa Rebellato**; Delson João da Costa***; Rafaela Scariot*** \& Leandro Eduardo Klüppel***

TRENTO, G. S.; PRIMO, B. T.; CORSO, P. F. C. L.; REBELLATO, N. L. B.; DA COSTA, D. J.; SCARIOT, R. \& KLÜPPEL, L. E. Treatment of Zygomatic-Orbital Complex Fracture Through Transconjunctival Approach. Int. J. Med. Surg. Sci., 2(1):420-425, 2015.

SUMMARY: Fractures of the zygomatic-orbital complex have been described as common in the midface traumas. The surgical approach election is an important decision when there is a risk of interference to function, aesthetics or an association of both. The pursuit of techniques that offer adequate visualization of the interested area associated with low morbidity has been responsible for the development of new techniques and materials. The better approach still remains with a lot of controversy among different authors. However, the transconjunctival incision can be considered in access fractures of the zygomatic-orbital complex. The purpose of this study is report a case of performing transconjunctival approach associated with lateral canthotomy to treatment of zygomatic-orbital complex fractures caused by sports trauma of a 34 years-old male patient.

KEY WORDS: Orbital fractures; Zygomatic fractures; Facial Injuries.

\section{INTRODUCTION}

In the context of traumatology, facial trauma stands out for the physical and emotional repercussions beyond possiblity of permanent damage. Compared to other areas of the body, the high rate of traumatic injuries in this region due to the large display and little protection of the facial region. The mandible, the nasal bone, the zygomatic arch, and, more broadly, the zygomatic-orbital complex have a higher prevalence among all the structures involved (Kontio \& Lindqvist, 2009).

More precisely, traumatized patients with compromised zygomatic-orbital complex may present periorbital edema and ecchymosis; sinking of the zygomatic prominence; presence of bone step in zygomatic-alveolar crest, orbital margin, and zygomatic arch; enophthalmous; ocular proptosis; ophthalmoplegia; ocular diplopia and dystopia; subconjuctival ecchymosis; trismus; pain; and paresthesia of the infraorbital nerve.

First reported by Bourget (1924) as an aesthetic access for blepharoplasty, the transconjunctival incision has been described and performed in orbital trauma since 1970. Surgeons state that the transconjunctival approach promote an excellent access to fracture reduction and fixation minimizing skin incision (Kushner, 2006). Nowadays, this incision is performed to access the orbital floor, and also the medial and lateral wall (Tenzel \& Miller, 1971; Moe et al., 2010).

* Resident, Department of Oral and Maxillofacial Surgery at Federal University of Paraná, Curitiba, Brazil.

** Chairman, Department of Oral and Maxillofacial Surgery at Federal University of Paraná, Curitiba, Brazil.

${ }^{* * *}$ Associated Professor, Department of Oral and Maxillofacial Surgery at Federal University of Paraná, Curitiba, Brazil. 


\section{CASE REPORT}

A 34 years old, male patient reported trauma in the right orbital region during sports activity. Initially examined, the patient was conscious, normal vital signs, pain, and sensibility alteration in the right zygomatic region. Physical examination identified right periorbital edema and ecchymosis (Fig. 1A), and sinking of the zygomatic area changing the anteroposterior dimension of the face (Fig. 1B). Intraoral examination revealed bruising in maxillary vestibule and zygomaticomaxillary buttress deformity. Palpable steps in bone apophyses region indicated fracture of the zygoma. Computerized tomography showed fracture of the right zygomaticomaxillary buttress and infraorbital rim (Figs. 2A and $2 \mathrm{~B}$ ). In axial section, CT revealed moderate edema, zygomatic bone fracture with loss of anteroposterior face projection, and fracture of the anterior wall of the maxillary sinus (Fig. 2C).

\section{Under}

general

anesthesia, firstly was performed an incision in the maxillary vestible to access the zygomaticomaxillary buttress.

Then, transconjunctival approach associated with lateral canthotomy to access the infra-orbital margin was carried out (Figs. 3A and 3B). After total exposure of the fractured fragments, with the aid of a periostal elevator, zygomatic buttress was reposiotioned observing
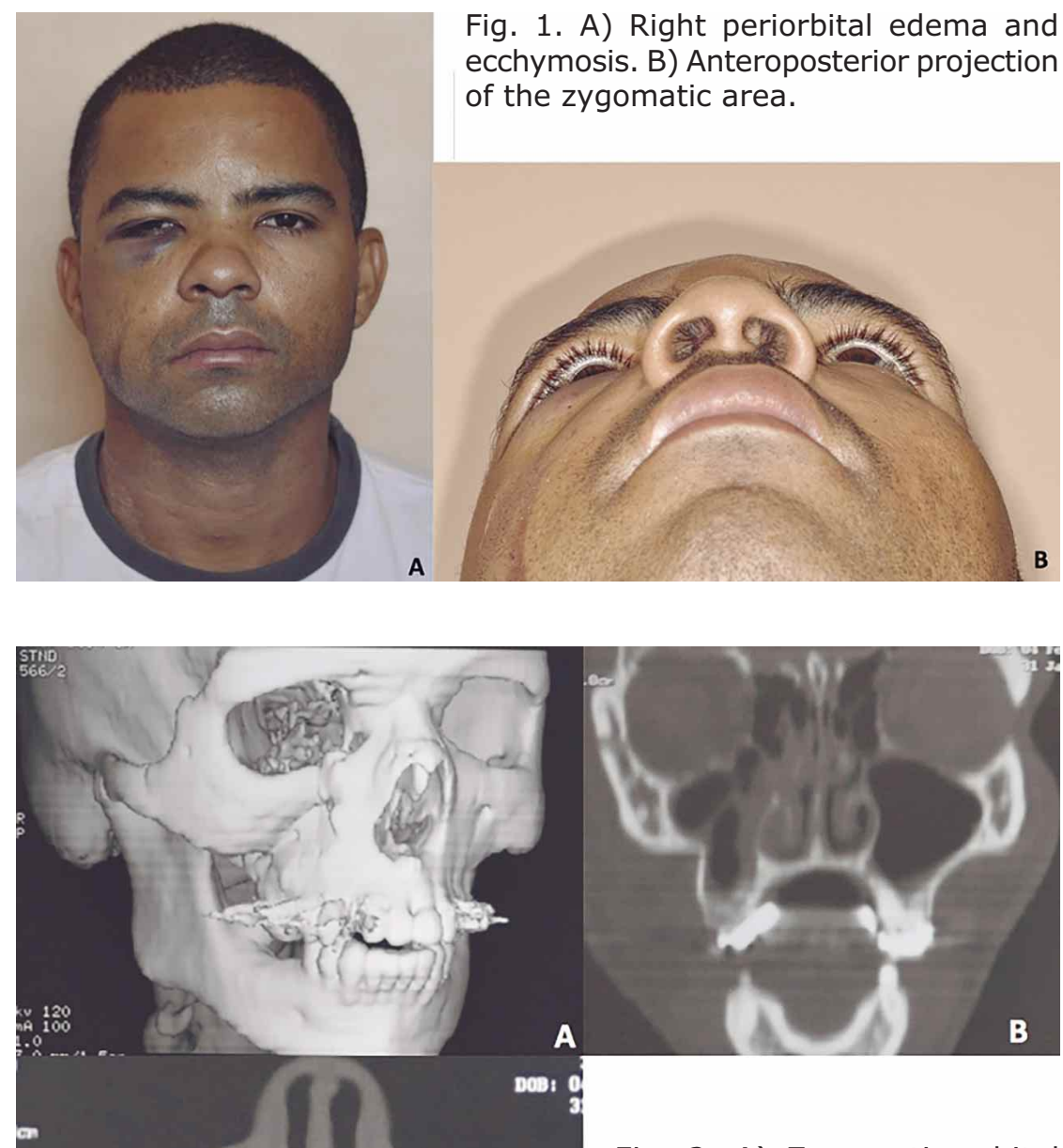

Fig. 2. A) Zygomatic-orbital complex fracture. B) Zygomatic buttress fracture and integrity preservation of the orbital floor. C) Veiling maxillary sinus and anterior wall fracture. concomitant reduction of the orbital margin. Titanium miniplates and screws were used to perform fixation (Fig. 3C and 3D).

Twelve months postoperative follow-up was carried out uneventfully. Ocular mobility and visual acuity were preserved. Also, restoration of anteroposterior projection of the midface could be seen (Fig. 4A). Imaging exams showed adequate alignment of the fractured segments with no herniation of the periorbital tissues (Fig. 4B). 


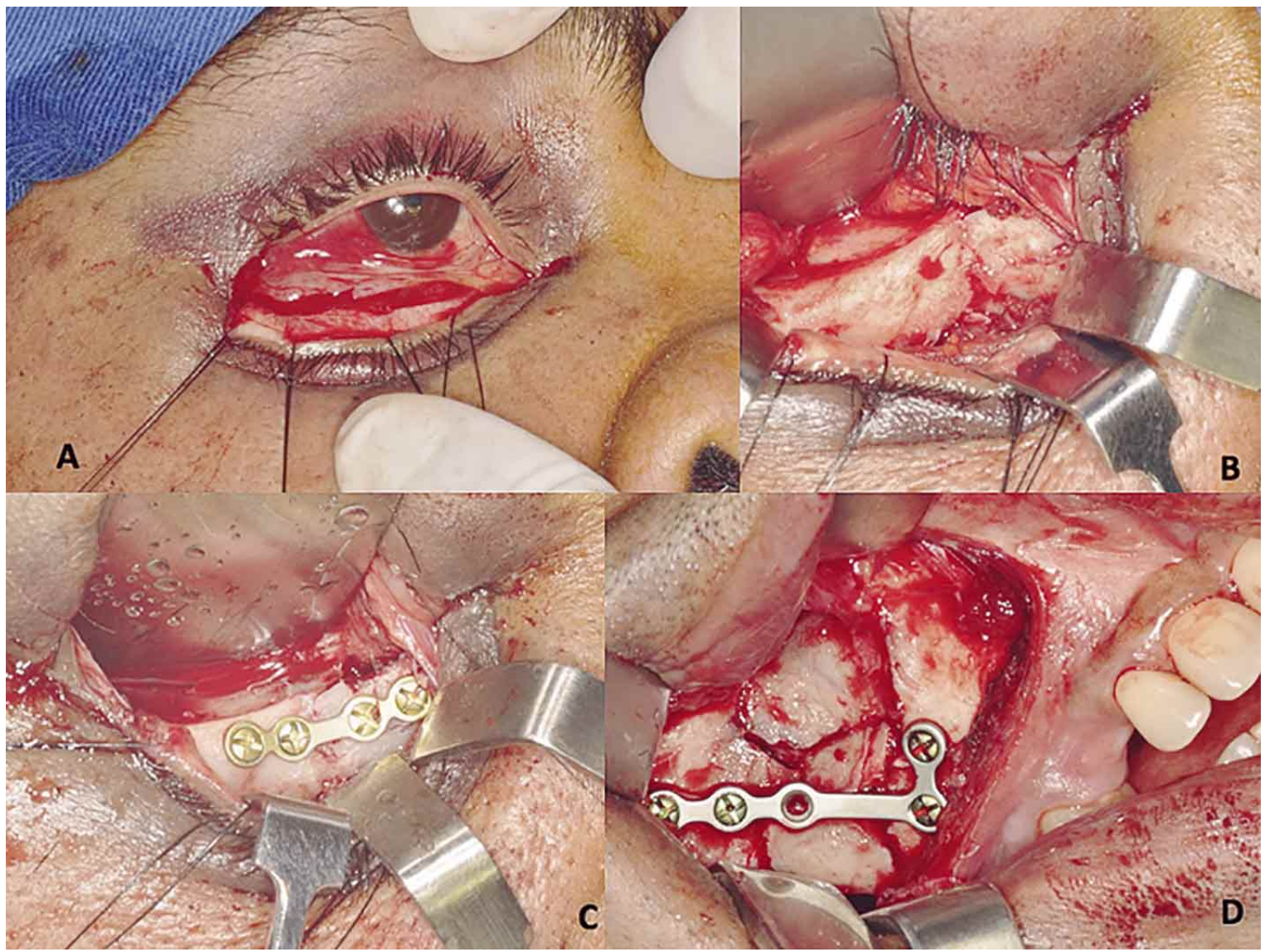

Fig. 3. A) Transconjunctival approach combined to lateral contatomy. B) Inferior rim fracture exposure. $C$ and $D$ ) Reduction and fixation of the orbital and maxillary fractures..

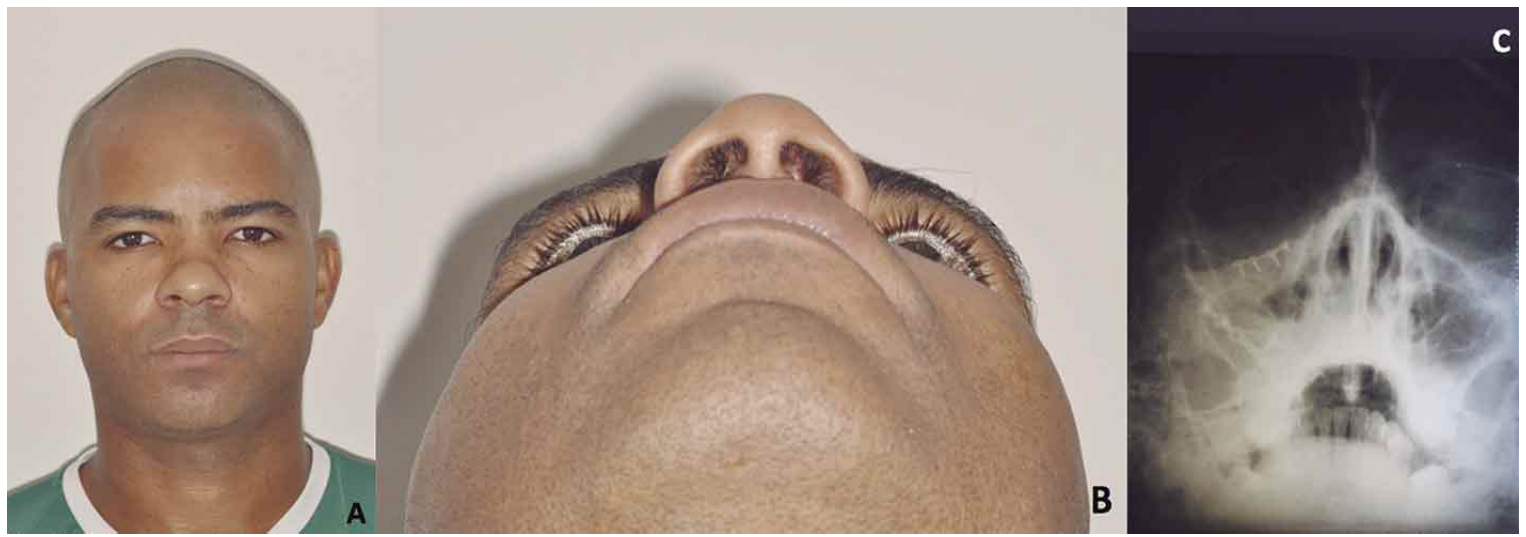

Fig. 4. A and B) Reestablishment of the face dimensions and no visual scar tissue. C) Titanium miniplantes and screws preserved in position.

\section{DISCUSSION}

Orbital fractures can be classified as pure (includes orbital internal region and its rims) and, more prevalently, impures (zygomaticorbital and naso-orbito-ethmoid fractures) (Ellis et al., 1985; Hammer, 1996). It is important to recognize the involvement of relevant aspects for ocular function and possibility of complications such as eyeball fixation by muscle 
TRento, G. S.; PRIMo, B. T.; CORSo, P. F. C. L.; REBellato, N. L. B.; DA COSTA, D. J.; SCARIOT, R. \& KLÜPPEL, L. E. Treatment of ZygomaticOrbital Complex Fracture Through Transconjunctival Approach. Int. J. Med. Surg. SCi, 2(1):420-425, 2015.

or periocular tissues clamping or optic nerve compression or laceration of periocular tissue. Therefore, surgeons should consider the possible consequences resulting from this type of trauma (Hammer; Kontio \& Lindqvist). Early identification based on signs and symptoms and tomographic assessment will dictate the type of treatment, that may vary from simple preservation to complex orbital wall reconstructive procedures.

Several techniques have been described to surgically treat patients with fractures of the zygomatic complex. However, fractures involving orbital floor and rim are usually treated performing subciliary or infraorbital incision, and the approach to the fronto-zygomatic area could be from the eyebrow incision (Manganelo-Souza \& Rodrigues de Freitas, 1997). Nevertheless, transconjunctival incision is understood as a versatile and appropriate approach to the medial wall of the orbit which promotes adequate exposure without affecting the lacrimal drainage system and the medial canthus allowing a wide view of the floor and inferior rim of the orbit, similar to eyelid incision but without secondary scars (Lynch et al., 1974; Gotsfrind, 1985; Ellis, 2012).

Manganello-Souza \& Rodrigues de Freitas described 40 patients who presented orbit floor fracture isolated or associated to other facial fractures who underwent transconjunctival approach. Seven patients that presented diplopia before the surgery related the disappearence of symptoms after surgery; five patients presented complications (ectropion, entropion, corneal ulcer, lower displacement of the lateral canthus). Novelli et al. (2011) reported 7\% of complications in 56 cases in which transconjunctival approach was performed. All the complications were resolved with simple eyelid massages within two months (Novelli et a/.).

Baumann \& Ewers (2001) described the transconjunctival access as safe and low incidence of early and late complications. Other authors have used only transconjunctival incision as periorbital access to treat fractures of the orbital floor, inferior rim, and lateral rim. They confirmed that association of a lateral cantotomy leads to a minimal scar tissue and low variety of complications (Shemen \& Meltzer, 1986; Manson et al., 1987; Waite \& Carr, 1991).
Currently, there is a great discussion about the advantages and disadvantages of transcutaneous and transconjunctival access to the orbital floor and infraorbital rim (Sebastiani et al., 2014). Some studies have compared the transconjunctival access with transcutaneous and the results showed that the transconjunctival approach causes lower incidence of ectropion rates and problems with the eyelid position (Patel et al., 1998; Jocono \& Moscowitz, 2001).

As contraindications and limits of the transconjunctival access can mention injuries and laceration of the inferior eyelid, orbital roof fracture, naso-orbital-ethmoid fractures, conjunctival disorders, ocular surface diseases or glaucoma (Magnus et al., 1971).

In more complex cases of zygomaticorbital fractures may perform the transconjunctival approach combined with lateral cantotomy. Simultaneous exposure of the infra-orbital and lateral rims is the greater advantage of this technique when compared to others (Jackson et al., 1987; Ilankovan, 1991; De Riu et al., 2008). The anterior portion of the zygomatic arch can be visualized through the transconjunctival approach associated to lateral cantotomy. Inferior cantholysis should be performed and detachment of the lateral canthal ligament of the superior buttress should be avoided when possible. Thus, reconstruction of the lateral canthus will be easier and the final results will be more favorable. Inferior cantotomy must be performed in order to avoid excessive incisions of the conjunctiva facilitating suturing and preventing lacerations (Fedok, 1996).

\section{CONCLUSION}

Transconjunctival approach proved to be effective since it provides adequate exposure of the surgical area in relation to zygomaticorbital complex fracture involving infra-orbital rim. Furthermore, it allows restoration of the function and aesthetics and imperceptible scar tissue. As well as any type of surgical approach, this technique requires the surgeon knowledgment and practice. 
TRENTO, G. S.; PRIMo, B. T.; CORSO, P. F. C. L.; REBelLATO, N. L. B.; DA COSTA, D. J.; SCARIOT, R. \& KLÜPPEL, L. E. Treatment of ZygomaticOrbital Complex Fracture Through Transconjunctival Approach. Int. J. Med. Surg. Sci., 2(1):420-425, 2015.

TRENTO, G. S.; PRIMO, B. T.; CORSO, P. F. C. L.; REBELLATO, N. L. B.; DA COSTA, D. J.; SCARIOT, R. \& KLÜPPEL, L. E. Tratamiento de la fractura del complejo cigomático-orbital mediante el acceso transconjuntival. Int. J. Med. Surg. Sci., 2(1):420-425, 2015.

RESUMEN: Fracturas del complejo cigomático-orbital se han descrito como común en el trauma del tercio medio facial. La elección de la incisión es una decisión importante cuando existe riesgo de interferencia con la función, la estética o una asociación de ambos. La búsqueda de técnicas que ofrecen uma visualización adecuada de la zona de interés asociado con una baja morbilidad ha sido responsable del desarollo de nuevas técnicas y materiales. El mejor enfoque sigue siendo ha sido de mucha controversia entre los diferentes autores. Sin embargo, la incisión transconjuntival puede ser considerada en las fracturas de acceso del complejo cigomático-orbital. El propósito de este estudio fue reportar un caso de abordaje transconjuntival asociado a contotomía lateral para el tratamiento de las fracturas del complejo cigomáticoorbital causado por trauma deportivo de un paciente masculino de 34 años de edad.

PALABRAS CLAVE: Fractura orbital; Fracturas cigomáticas; Lesiones faciales.

\section{REFERENCES}

Baumann, A. \& Ewers, R. Use of the preseptal transconjunctival approach in orbit reconstruction surgery. J. Oral Maxillofac. Surg., 59(3):287-91, 2001.

Bourget, J. Les hernies graisseuses de I'orbite: Notre traitement chirurgical. Bull. Acad. Med. Paris, 92:1270-2, 1924.

De Riu, G.; Meloni, S. M.; Gobbi, R.; Soma, D.; Baj, A. \& Tullio, A. Subciliary versus swinging eyelid approach to the orbital floor. J. Craniomaxillofac. Surg., 36(8):439-42, 2008.

Ellis, E. 3rd. Orbital trauma. Oral Maxillofac. Surg. Clin. North Am., 24(4):629-48, 2012.

Ellis, E. 3rd. ; el-Attar, A. \& Moos, K. F. An analysis of 2,067 cases of zygomatico-orbital fracture. J. Oral Maxillofac. Surg., 43(6):417-28, 1985.

Fedok, F. G. The transconjunctival approach in the trauma setting: avoidance of complications. Am. J. Otolaryngol., 17(1):16-21, 1996.

Gotsfried, H. F. Combination of miniplate osteosynthesis and transconjunctival approach for reduction of zygomaticfractures. In: Oral and Maxillofacial Surgery. Proceedings from the 8th International conference on oral and maxillofacial surgery. Chicago, Quintessence, 1985. pp.22939.

Hammer, B. Orbital Fractures: Diagnosis, Operative Treatment, Secondary Corrections. Toronto, Hogrefe \& Huber Publishers, 1995.
Ilankovan, V. Transconjunctival approach to the infraorbital region: a cadaveric and clinical study. Br. J. Oral Maxillofac. Surg., 29(3):169-73, 1991.

Jackson, I. T.; Schiele, U. U. \& Adham, M. The conjunctival approach to the orbital floor and maxilla--advantages and disadvantages. Ann. Plast. Surg., 19(1):46-8, 1987.

Jocono, A. A. \& Moskowitz, B. Transconjunctival versus transcutaneous approach in upper and lower blepharoplasty. Facial Plast. Surg., 17(1):21-8, 2001.

Kontio, R. \& Lindqvist, C. Management of orbital fractures. Oral Maxillofac. Surg. Clin. North Am., 21(2):209-20, 2009.

Kushner, G. M. Surgical approaches to the infraorbital rim and orbital floor: the case for the transconjunctival approach. J. Oral Maxillofac. Surg., 64(1): 108-10, 2006.

Lynch, D. J.; Lamp, J. C. \& Royster, H. R. The conjunctival approach for exploration of the orbital floor. Plast. Reconstr. Surg., 54(2):153-6, 1974.

Magnus, W. W.; Castner, D. V.; Schonder, A. A. \& Salz, J. J. A conjunctival approach to repair of fracture of medial wall of orbit: report of case. J. Oral Surg., 29(9):664-7, 1971.

Manganelo-Souza, L. C. \& Rodrigues de Freitas, R. Transconjunctival approach to zygomatic and orbital floor fractures. Int. J. Oral Maxillofac. Surg., 26(1):31-4, 1997. 
TRENTO, G. S.; PRIMO, B. T.; CORSO, P. F. C. L.; REbellato, N. L. B.; DA COSTA, D. J.; SCARIOT, R. \& KLÜPPEL, L. E. Treatment of ZygomaticOrbital Complex Fracture Through Transconjunctival Approach. Int. J. Med. Surg. Sci., 2(1):420-425, 2015.

Manson, P. N.; Ruas, E.; Iliff, N. \& Yaremchuk, M. Single eyelid incision for exposure of the zygomatic bone and orbital reconstruction. Plast. Reconstr. Surg., 79(1):120-6, 1987.

Moe, K. S.; Bergeron, C. M. \& Ellenbogen, R. G. Transorbital neuroendoscopic surgery. Neurosurgery, 67(3 Suppl. Operative):ons16-28, 2010.

Novelli, G.; Ferrari, L.; Sozzi, D.; Mazzoleni, F. \& Bozzetti, A. Transconjunctival approach in orbital traumatology: a review of 56 cases. J. Craniomaxillofac. Surg., 39(4):266-70, 2011.

Patel, P. C. ; Sobota, B. T.; Patel, N. M. ; Greene, J. S. \& Millman, B. Comparison of transconjunctival versus subciliary approaches for orbital fractures: a review of 60 cases. J. Craniomaxillofac. Trauma, 4(1):17-21, 1998.

Sebastiani, A. M.; Trento, G. S.; Antonini, F.; Kluppel, L. E. ; Scariot, R. ; da Costa, D. J. \& Rebellato, N. L. B. Cicatricial ectropion correction in inferior eyelid with cartilaginous tissue graft: Case report. Int. J. Med. Surg. Sci., 1(3):217-22, 2014.

Shemen, L. J. \& Meltzer, M. "How i do it" - head and neck and plastic surgery: A targeted problem and its solution: Inferior fornix incision for orbital rim and floor fractures. Laryngoscope, 96(10):11647, 1986.

Tenzel, R. R. \& Miller, G. R. Orbital blow-out fracture repair, conjunctival approach. Am. J. Ophthalmol., 71(5):1141-2, 1971

Waite, P. D. \& Carr, D. D. The transconjunctival approach for treating orbital trauma. J. Oral Maxillofac. Surg., 49(5):499-503, 1991.
Correspondence to:

Guilherme dos Santos Trento

Department of Oral and Maxillofacial Surgery

Federal University of Paraná, Curitiba

632th Prof. Lothario Meissner Street

Jardim Botânico

Curitiba

Paraná

BRAZIL

ZIPCODE: 80210170

Phone: +55 $413360-4020$

Email: guilhermetrento@yahoo.com.br

Received: 11-02-2015

Accepted: 22-03-2015 